\title{
RELASI LAKI-LAKI DAN PEREMPUAN (Menabrak Tafsir Teks, Menakar Realitas)
}

\author{
Achmad Mulyadi \\ (Jurusan Syari'ah STAIN Pamekasan, Jl. Raya Panglegur km. 04 Pamekasan, \\ email: didiek71@gmail.com)
}

\begin{abstract}
Abstrak
Istilah jender dianggap sebagai diferensiasi pria-wanita. Perbedaan ini muncul karena realitas budaya yang dibangun oleh masyarakat. Konsep ini bertentangan dengan seks, yang membedakan istilah pria-wanita secara biologis. Dengan demikian, perbedaan seks adalah konstruksi Allah, dan tidak dapat dikaji kembali. Di sisi lain, perbedaan jender adalah konstruksi sosial dan dapat dikaji kembali (qâbil li al-niqasy). Oleh karena itu, konsep relasi pria-wanita selalu diperdebatkan dalam hal baik dalam studi teks atau dalam konteks realitas di masyarakat. Artikel ini menguraikan pembentukan relasi pria-wanita dari perspektif teks, konstruksi budaya dan hari ini realitasnya. Dalam konteks ini, banyak tafsiran terhadap teks-teks sumber hukum Islam (alQur'an dan al-Hadits) justru menguatkan budaya patrilineal. Tradisi yang bias jender ini mengakar kuat dalam masyarakat. Walaupun demikian, hal yang tidak bisa diingkari adalah perubahan realitas. Saat ini mulai tampak bahwa peran-peran yang secara budaya dikonsepsikan untuk laki-laki justru dilakukan oleh perempuan. Fenomena ini merupakan wujud perubahan realitas, yang akan memunculkan budaya baru yang egaliter.
\end{abstract}

\footnotetext{
Abstract

The term of jender has been perceived as man-woman differentiation. The distinction is appeared due to cultural reality constructed by society. This concept is opposed to sex, which differentiate the terms of man-woman biologically. Thus, the difference in sex is a God construction, and cannot be restudied. On the other hand, the difference in gender is a social construction and it can be restudied (qâbil li al-niqasy). Therefore, a gender concept on man-woman relation is always debatable in terms either in text study or in its reality context in the society. This article elaborates the establishment of man-
} 
Achmad Mulyadi

woman relation from the text perspective, cultural construction and its reality today. In this context, many interpretations of the texts on Islamic law (the Qur'an and Hadits) actually reinforce patriarchal culture. The tradition is deeply entrenched gender bias in society. However, it can not be denied is the reality of change. Today, it began to appear that the roles are culturally conceived for men it is done by women. This phenomenon is a form of reality changes, which will bring a new culture that is egalitarian.

\section{Kata-kata Kunci}

jender, tafsir, teks, budaya, dan realitas

\section{Pendahuluan}

Isu jender menjadi sangat menarik ketika dihubungkan dengan wacana keislaman, yang memang merupakan salah satu komponen dalam berbagai perubahan sosial, kebudayaan dan bahkan politik. Berbagai upaya telah dilakukan untuk mengembangkan isu tersebut mulai dari dekonstruksi khazanah Islam sampai pada upaya rekonstruksinya. Salah satu yang menjadi pokok kajiannya adalah problem relasi laki-laki dan perempuan.

Dalam konteks relasi tersebut, laki-laki selalu dipersepsikan memiliki wilayah peran publik dan perempuan dianggap sebagai penguasa dan penentu peran domestik. Karena itu, keduanya diasumsikan mempunyai wilayah aktualisasi diri yang berbeda. Sekat budaya ini, menurut kaum feminis, merupakan warisan kultural dan budaya baik dari masyarakat primitif, masyarakat agraris, maupun masyarakat modern. Di sisi lain banyak pemahaman terhadap teks ditemukan memperkuat bahkan ikut andil dalam melanggengkan kontruksi budaya tersebut, yang nota bene teks-teks tersebut diturunkan pada budaya Arab yang patriarkhis, sehingga tafsiran tersebut selalu berbias jender. Padahal dalam pendekatan yang berbeda didapatkan banyak teks yang justru mendukung kesetaraan relasi laki-laki dan perempuan.

Dari konteks tersebut dapat dielaborasi bahwa konsep relasi laki-laki dan perempuan muncul dan berkembang mulai dari hasil pemahaman terhadap teks dan konstruksi budaya, sehingga saat ini ditemukan wujud realitas yang berbeda.

\section{Pemahaman Teks dan Konstruksi Budaya}


Dalam konteks relasi laki-laki dan perempuan terdapat dua wilayah peran yang diperhadapkan yaitu peran publik (public role) atau sektor publik (public sphere) dengan peran domestik (domestic role) atau sektor domestik (dometic sphere). Istilah pertama biasanya diasumsikan sebagai wilayah aktualisasi diri kaum laki-laki, sementara yang kedua dianggap sebagai dunia kaum perempuan. Sekat budaya ini, menurut kaum feminis, merupakan warisan kultural dari masyarakat primitif yang menempatkan laki-laki sebagai pemburu (hunter) dan perempuan sebagai peramu (gatherer).

Warisan tersebut selanjutnya diteruskan oleh masyarakat agraris yang menempatkan laki-laki di luar rumah (public sphere) untuk mengelola pertanian dan perempuan di dalam rumah (domestic sphere) untuk mengurus keluarga. Demikian juga, dalam masyarakat modern, sekat budaya tersebut masih cenderung diakomodasi, terutama dalam sistem kapitalis. Padahal pembagian kerja yang berdasarkan jenis kelamin seperti ini, bukan saja merugikan kaum perempuan itu sendiri, ${ }^{1}$ namun juga sangat tidak relevan lagi untuk diterapkan di era sains dan teknologi yang serba modern ini. ${ }^{2}$

Perbedaan peran antara laki-laki dan perempuan dalam masyarakat secara umum dapat dikategorikan dalam dua kategori besar: Pertama, teori nature, yang menyatakan bahwa perbedaan peran laki-laki dan perempuan ditentukan oleh faktor biologis. Menurut teori ini, sederet perbedaan biologis antara laki-laki dan perempuan menjadi faktor utama dalam penentuan peran sosial kedua jenis kelamin. Kedua, teori nurture, yang mengungkapkan bahwa perbedaan peran sosial lebih ditentukan oleh faktor budaya. Menurut teori ini pembagian peran laki-laki dan perempuan dalam masyarakat

1 Dalam studi yang menggunakan analisis jender ternyata banyak ditemukan berbagai manifestasi ketidakadilan, yaitu: Pertama, terjadi marginalisasi terhadap kaum perempuan; kedua, terjadi subordinasi pada satu jenis kelamin, umumnya kepada kaum perempuan; ketiga, pelabelan negatif terhadap (stereotipe) dan diskriminasi terhadap jenis kelamin tertentu; keempat, kekerasan (violence) terhadap jenis kelamin tertentu, umumnya kepada perempuan, dan kelima, karena peran jender perempuan adalah mengelola rumah tangga, maka banyak perempuan menanggung beban kerja lebih banyak dan lebih lama (burden). Lihat Mansour Fakih, Analisis Gender E Transformasi Sosial, (Yogyakarta: Pustaka Pelajar, 1999), hlm 72-75.

2 Syarif Hidayatullah "Al-Qur'an dan Peran Publik Perempuan", dalam Gender dan Islam: Teks dan Konteks, ed. Waryono Abdul Ghafur dan Muh. Isnanto (Yogyakarta: PSW IAIN Sunan Kalijaga), hlm. 5-7 
Achmad Mulyadi

tidak ditentukan oleh faktor biologis, melainkan dikonstruksikan oleh budaya masyarakat. ${ }^{3}$

Salah satu contoh kesetaraan peran publik perempuan adalah wacana perempuan menjadi kepala negara. Diakui secara mutlak, bahwa dalam diskursus ini memang tidak ada pernyataan langsung dari al-Qur'an tentang peran publik perempuan, akan tetapi juga sebaliknya tidak ditemukan secara tegas menyatakan penolakan terhadap kekuasaan Ratu Saba sebagai pemimpin Yaman Selatan. Bahkan, dalam al-Qur`an, Ratu Saba digambarkan sebagai Ratu yang independen, tidak terpengaruh dari pejabat laki-laki dalam mengambil kebijakan politiknya, Ratu yang sah dan bijaksana. Dengan demikian, al-Qur`an memandang laki-laki dan perempuan dalam berbagai terminologi kesetaraan sebagai makhluk manusia dalam berbagai hal. Keseluruhan spirit Islam secara umum sangat menegaskan kesetaraan kedua jenis seks tersebut baik dalam status, posisi dan nilai.

Dari pola pikir di atas, perempuan harus memainkan peranan yang lebih besar dalam era ekonomi industri modern karena tidak ada ajaran al-Qur`an yang menghalangi perempuan bekerja dan bahkan dianjurkan untuk memperkuat kiprah publiknya. Implikasinya, perempuan memiliki beban ganda (double burden), beban yang muncul dari peran domestiknya sekaligus beban baru yang diperkuat dalam ranah publiknya. Dari satu sisi, perempuan perlu berusaha sendiri, tetapi di sisi lain harus lebih konsisten mengasuh anak dan mengurus keluarga. ${ }^{4}$ Realitasnya memberikan ekses yang berbeda, yaitu terdapat peran (ganda) yang diterima tersebut memberikan kebebasan kepada perempuan, akan tetapi ditemukan juga peran ganda tersebut semakin menjadi beban yang membelenggu.

Konteks tersebut dilihat dengan teori perbedaan antara teks dan realitas (contrasting between teks and reality) dan teori perbedaan antar nilai dan realitas (contrasting between values and reality). Teoriteori tersebut ini digunakan untuk menguji tentang sejauhmana teksteks dan nilai-nilai yang adil jender tersebut diaplikasikan dalam

3 Nasaruddin Umar, Argumen Kesetaraan Jender Perpsektif al-Qur'an, (Jakarta: Paramadina, 1999), hlm. 4-7

4 Ibid, hlm. 76 
realitas masyarakat sehingga dapat terlihat terjadinya dinamika peran dan relasi antara laki-laki dan perempuan. Meskipun demikian, melihat peran publik perempuan, dalam lintasan sejarah dan budaya, pembagian kerja secara seksual selalu ditemukan sehingga Michelle Rosaldo dan Louise Lamphere mengidentifikasikannya berdasarkan ciri-ciri universal dalam berbagai kelompok budaya ${ }^{5}$, pembagian kerja secara seksual tetap saja melanggengkan dominasi laki-laki terhadap perempuan.

Pemahaman ilmiah dan kultural terhadap perbedaan jenis kelamin tersebut menimbulkan perdebatan panjang, termasuk di kalangan ilmuwan-teolog dan feminis. Mereka memberikan andil penting dalam wacana ini karena penafsiran-penafsiran mereka terhadap kitab suci merujuk kepada kondisi obyektif lingkungan masyarakat di mana mereka berada. Tidak sedikit penafsiran mereka yang membenarkan konstruksi budaya yang hidup di dalam masyarakat. Namun sebaliknya, tidak sedikit konstruksi budaya dibangun di atas pemahaman kitab suci, misalnya persepsi al-Qur`an terhadap tiga hal pokok tentang perempuan:6 Pertama, tujuan penciptaan perempuan untuk melengkapi kebutuhan laki-laki (Adam) di Surga. Pemahaman semacam ini mengesankan bahwa perempuan hanyalah pelengkap dan diciptakan untuk melayani kebutuhan laki-laki. Kedua, perempuan diciptakan dari tulang rusuk laki-laki. Analisis semacam ini mengesankan perempuan subordinat. Ketiga, perempuan sebagai penyebab jatuhnya manusia dari surga ke bumi. Hal ini mengesankan perempuan sebagai penyebab dosa warisan. Ketiga pemahaman tersebut membentuk persepsi yang

5 Terdapat berbagai kelompok budaya yang memiliki karakteristiknya sendiri. Pertama,masyarakat pemburu dan peramu. Dalam kelompok masyarakat ini, semakin besar jumlah hasil buruan semakin besar pula kekuasaan yang diperoleh laki-laki. Kedua, masyarakat holtikultura, yang pola relasi jendernya memiliki keseimbangan, hanya saja peran politiknya masih didominasi laki-laki. Ketiga, masyarakat agraris. Dalam masyarakat agraris, pola relasi jendernya ditandai dengan ciri-ciri masyarakat patriarkhi, peranan laki-laki lebih besar dari perempuannya. Dan keempat, masyarakat industri. Dalam kelompok masyarakat ini, meskipun perempuan diberikan peluang berkiprah di sektor publik, akan tetapi persyaratannya cukup berat karena peran reproduksinya tidak dianggap sebagai peran ekonomi (uneconomic role) sehingga standar yang digunakan adalah standar ganda, karena itu dianggap sebagai era baru sistem patriarkhi (the neopatriarchical era). Lihat Ibid, hlm 80-84.

6 Ibid., hlm. 4-7 
mengendap di alam sadar masyarakat sehingga mereka memandang bahwa perempuan memang tidak pantas disejajarkan dengan lakilaki.7

Dalam pada itu, konsep jender (relasi laki-laki dan perempuan) dalam Islam masih menjadi perdebatan di kalangan umat Muslim. Sebagian kalangan berpendapat bahwa jender dalam Islam tidak ada masalah, dan sebagian yang menganggapnya ada masalah dan pandangan status quo tentang jender sudah saatnya digugat $^{8}$. Bila dicermati, pangkal perbedaan pendapat mereka sebenarnya terletak pada masalah interpretasi ayat. Karena itu, persoalan krusial yang perlu dikaji adalah menimbang perspektif "keIslam-an" terhadap kedua pendapat tersebut.

Penafsiran terhadap al-Qur`an surat al-Nisâ' ayat 4 seringkali dijadikan landasan justifikatif "superioritas" laki-laki (suami) atas perempuan (istri). Kata qawwâmûn dalam ayat tersebut dipahami terlepas dari advokasi Qur'anik lainnya tentang pembentukan kehidupan keluarga sehingga muncul klaim adanya relasi jender dalam lingkup domestik. ${ }^{9}$ Padahal jika dihubungkan dalam kerangka pemahaman ideal moral al-Qur`an tentang tujuan

7 Hidayatullah, "Al-Qur'an dan Peran Publik Perempuan", hlm. 6

8 Legitimasi ajaran agama terhadap tradisi patriarkhal dapat ditelusuri dalam dua perspektif, yaitu perspektif sosiologis dan teologis. Dalam perspektif sosiologis, relasi jender dipahami sebagai institusi sosial yang terorganisasi antara laki-laki dan perempuan yang meliputi hubungan personal dan kekeluargaan sampai hubungan institusi sosial yang lebih besar, hubungan hierarkis dalam organisasi dan struktur pekerjaan. Dalam hubungan ini, jender merupakan proses sosiologis yang dapat berubah sesuai dengan perubahan faktor-faktor pembentuknya. Masuknya tradisi patriarkhal berawal dari pemahaman jender yang tereduksi. Relasi jender dipahami sama dengan relasi seks. Kerangka berpikir sex differences yang diberlakukan sama dengan jender differences pada akhirnya akan melahirkan perlakuan diskriminatif terhadap perempuan. Sedangkan dalam perspektif teologis meliputi legitimasi ajaran teologi dan tradisi keagamaan yang masuk dari wacana dinamis pembacaan teks keagamaan, yang terdapat dalam tradisi tafsir dan tradisi periwayatan tafsir. Dalam kedua tradisi tersebut ditemukan penafsiran yang patriarkhal seperti laki-laki adalah pemimpin wanita atau perempuan adalah sumber bencana. Lihat Kadarusman, Agama, Relasi Gender dan Feminesme, (Yogyakarta: Kreasi Wacana, 2005), hlm. 4-5

9 Munculnya penafsiran bias jender boleh jadi disebabkan oleh beberapa hal. Pertama, belum jelasnya perbedaan antara sex dan gender dalam mendefinisikan laki-laki dan perempuan; kedua, pengaruh kisah-kisah isrâiliyat; ketiga, menggunakan pendekatan tekstualistik; dan keempat, pembacaan terhadap ayat-ayat jender secara parsial. Lihat, Umar, Argumen Kesetaraan Jender, hlm. 21 
perkawinan, tata pergaulan suami-istri dan tanggung jawab keluarga, maka klaim di atas merupakan akibat dari pemahaman simplistikparsialistik (menyederhanakan dan tidak menyeluruh) terhadap alQur'an. Dominannya pola pemahaman semacam ini turut andil menutupi "keluhuran" Islam orisinal dengan "bopeng" Islam historis. Lebih jauh dari pemahaman tersebut, al-Qur'an semestinya ditangkap makna substansialnya sehingga selalu relevan dengan tantangan dan perkembangan zaman.10

Al-Qur’an tidak memberikan beban jender secara mutlak dan kaku kepada seseorang namun bagaimana agar adanya kewenangan manusia untuk menggunakan kebebasannya dalam memilih pola pembagian peran laki-laki dan perempuan yang saling menguntungkan, baik sektor domestik maupun sektor publik. ${ }^{11}$ Dalam konteks ini, terdapat beberapa alasan munculnya dorongan alQur'an ke arah kesetaraan perempuan dan laki-laki. Pertama, alQur`an memberikan tempat yang terhormat kepada seluruh manusia, yang meliputi perempuan dan laki-laki. Kedua, secara norma-etis alQur`an membela prinsip-prinsip kesetaraan perempuan dan laki-laki. Perbedaan struktur biologis, menurut al-Qur`an, tidak berarti ketidaksetaraan dan status yang didasarkan pada jenis kelamin, melainkan terdapat perbedaan antara fungsi-fungsi biologis dengan fungsi-fungsi sosialnya. ${ }^{12}$ Dalam kaitan ini, Islam menegaskan prinsip-prinsip yang mendukung eksistensi keadilan jender, yaitu: Pertama, bahwa laki-laki dan perempuan sama-sama memiliki peluang dan potensi untuk menjadi hamba Allah yang ideal, mencapai derajat puncak spiritualitas yang paling tinggi yakni muttaqîn. Kedua, bahwa laki-laki dan perempuan adalah sebagai khalîfah Allah di bumi yang sama-sama memiliki tugas untuk

${ }^{10}$ Hamim Ilyas, Studi Kitab Tafsir, (Yogyakarta: Teras, 2004), hlm. 20

11 Nabi secara radikal telah mendobrak pengurungan perempuan hanya sebagai makhluk domestik saja dan ini telah dilakukan oleh umat awal. Dengan anjuran menuntut ilmu mengindikasikan bahwa Nabi membuka ruang publik sebagai ajang bagi kehidupan laki-laki maupun perempuan. Ajang pengamatan ilmu adalah kehidupan bersama, kehidupan publik yang tidak mungkin dibatasi. Karena itu membatasi ruang gerak perempuan hanya dalam ruang tembok rumah saja dan menganggapnya sebagai dogma agama adalah tidak berdasar. Lihat, Masdar F. Mas'udi, Islam dan Hak-hak Reproduksi Perempuan, (Bandung: Mizan, 1997), hlm. 56 12 Ali Asghar Engineer, Hak-Hak Perempuan dalam Islam, (Yogyakarta: LSPPA, 2000), hlm. 34 
Achmad Mulyadi

memakmurkan bumi. Ketiga, laki-laki dan perempuan sama-sama menerima dan mengemban amanah primordial. Keempat, laki-laki dan perempuan sama-sama terlibat dalam drama kosmis. Kelima, laki-laki dan perempuan sama-sama berpotensi untuk meraih prestasi. ${ }^{13}$

\section{Bias Jender dalam Tafsir dan Realitas}

Banyak kajian yang dihasilkan dari diskursus ini mulai dari pemahaman teks dan kontekstualitasnya. Syarif Hidayatullah dalam kajian al-Qur'an dan Peran Publik Perempuan mengurai bahwa tidak sedikit ayat al-Qur'an yang menegaskan adanya kesetaraan antara laki-laki dan perempuan di sesktor publik. Dengan ini jelas bahwa alQur'an tidak melakukan diskriminasi apa pun terhadap perempuan. Al-Qur`an bahkan menegaskan bahwa perempuan memiliki hak-hak sebagaimana yang dimiliki oleh laki-laki seperti hak memelihara identitas diri, hak memperoleh pendidikan dan hak berpartisipasi dalam politik dan persoalan publik lainnya. Senada dengan kajian tersebut, Waryono dan Nurjannah, Islam mengelaborasi kajian jender dalam khazanah tafsir al-Qur`an seperti Tafsîr al-Thabârî karya alThabârî dan Tafsîr Mafâtih al-Ghayb karya Fakhr al-Dîn al-Râzî menyatakan terhadap penciptaan manusia, khususnya yang berjenis kelamin perempuan, al-Qur`an tidak menjelaskannya dan HaditsHadits yang dijadikan sebagai dasar argumentasi ternyata adalah $d a^{\prime} \hat{f} f$, bahkan Hadits-Hadits yang berisi perempuan terlahir sebagai penggoda laki-laki bersifat kasuistik.

Di sisi yang lain, kajian Agus Moh Najib tentang Bias Jender dalam Kitab Figh berusaha memaparkan sebelas diktum yang bias jender dalam kitab Taqrib-nya Abu Syuja'. Demikian juga, Wawan Gunawan dalam Bias Jender dalam Khutbah Nikah dan Emah Marhumah dalam Perempuan dalam Kitab Assilah fi Bayan an-Nikah. Dua kajian terakhir ini memotret produk pemikiran agama di dua wilayah yang berbeda Jawa Barat dan Madura Jawa Timur. Kajian empirik tersebut meski tidak bisa dikatakan representasi dua budaya yang berbeda, namun setidaknya telah menggambarkan betapa faktor budaya telah menjadi sesuatu yang determinan serta mempengaruhi terjadinya bias jender.

13 Umar, Argumen Kesetaraan Jender, hlm. 247-263 
Secara konteks sosial-empirik, kajian relasi suami-istri baru dilakukan oleh Norwanto. Norwanto mengurai bahwa terjadi pergeseran relasi jender pada keluarga TKW. Keluarga yang ditinggalkan oleh istri harus melakukan proses dialektik alamiah untuk menjawab tantangan budaya baru. Ketidakseimbangan dalam ekosistem keluarga menghasilkan pergeseran peran jender sebagai tanggapan menuju keseimbangan baru. Ruang kosong yang ditinggal istri menjadi tanggung jawab bersama (kolektif) antara suami, orang tua atau kerabat lain. Kesadaran ini tidak terlepas dari pola kekerabatan dalam keluarga yaitu eratnya hubungan emosional antara keluarga inti dan keluarga luas. Norwanto lebih detail mengelaborasi bahwa terdapat tiga pola pergeseran peran, yaitu: Pertama, suami mengambil peran yang ditinggal istri; kedua, suami mengambil sebagian peran yang ditinggal istri; ketiga, suami tidak mengambil peran sama sekali. Pola tersebut dibagi menjadi sub pola, yakni suami bekerja dan suami tidak bekerja. Kondisi tersebut mengharuskan suami mengambil peran ganda, yaitu sebagai penggerak ekonomi keluarga dan sekaligus melakukan pekerjaan domestik.

Di samping itu, kajian yang mengelaborasi tentang posisi dan relasi perempuan pesisir telah dilakukan di daerah Hirar Bulukumba. Kajian tersebut menggambarkan tentang aktifitas yang dilakukan perempuan pada saat masyarakat laki-laki melaut. Ketika musim melaut, tidak ada lagi laki-laki dewasa, tinggal anak-anak dan perempuan, sehingga perempuan tidak hanya memerankan tugas domestiknya, akan tetapi harus melakukan kegiatan-kegiatan publiknya. Meskipun demikian, perempuan terkonstruksi tetap tidak bisa lepas dari posisi yang tertindas dan masyarakat secara umum serta pemerintah tetap menganggap perempuan tidak penting, dianggap seakan-akan ada laki-laki.

\section{Teks Egalitas dalam Al-Qur`an}

Secara normatif, ada beberapa teks al-Qur'an yang mengisyaratkan kesejajaran relasi laki-laki dan perempuan dalam segala aspek kehidupan, yaitu: Pertama, pernyataan umum tentang egalitas perempuan dan laki-laki. Dalam hal ini, al-Qur'an secara tegas menjelaskan bahwa istri adalah pasangan suami dan suami adalah pasangan istri. Keduanya digambarkan berfungsi sebagai baju 
(libas).14 Bahkan al-Qur`an menegaskan bahwa wanita mempunyai hak yang seimbang dengan kewajibannya. ${ }^{15} \mathrm{Kedua}$, asal usul kejadian manusia. Kesetaraan dalan asal usul kejadian manusia ditegaskan dalam dua ayat al-Qur'an. Penegasan ini dari bahwa manusia diciptakan dari jenis yang sama dan terdiri dari jenis laki-laki dan perempuan. ${ }^{16}$ Ketiga, 'amal. Kesetaraan karya dan reward-nya dapat dilihat dalam beberapa ayat. Al-Qur'an menegaskan bahwa 'amal laki-laki dan perempuan tidak akan sia-sia. Karya suami adalah baginya dan karya istri adalah baginya. ${ }^{17}$ Bahkan mukmin laki-laki dan perempuan sama-sama dijanjikan akan masuk surga, begitu juga yang berlaku jahat akan dijanjikan sebaliknya. Keduanya akan mendapat ganjaran yang setimpal, jika durhaka akan sesat dan jika minta ampun akan diampuni. ${ }^{18}$ Dan dalam konteks 'amal ini, unsur yang membedakan antara satu orang dengan orang lain adalah hanya nilai ketakwaannya. ${ }^{19}$ Keempat, saling kasih dan mencintai. Egalitas dalam hal ini dielaborasi secara tegas pula oleh al-Qur`an seperti pergaulan dalam keluarga harus diwarnai dengan sikap-sikap saling menyayangi dan menyenangkan. Bahkan, tujuan penciptaan keduanya pun untuk menciptakan ketentraman (sakînah), kasih sayang (rahmah) dan saling cinta (mawaddah). ${ }^{20}$ Kelima, keadilan dan persamaan. Teks al-Qur'an secara tegas pula menjunjung keadilan dan persamaan antar sesama termasuk antara laki-laki dan perempuan. Sebagaimana dijelaskan bahwa hak wanita dan laki-laki sesuai dengan kewajibannya, begitu juga balasan amal keduanya adalah sama tergantung pada hasil karyanya. ${ }^{21}$ Dengan demikian, kesempatan bekerja antar laki-laki dan perempuan mendapat peluang yang sama, tanpa membedakan jenis kelamin selama memenuhi syarat-syarat yang ditentukan dan halal. Bahkan dalam konteks yang lebih luas, keduanya dianjurkan untuk saling membantu dan tolong

\footnotetext{
${ }^{14}$ Al-Qur`an, al-Baqarah (2): 187

15 Al-Qur`an, al-Baqarah (2):228

16 Al-Qur`an, Al-Nisâ' (4):1 dan al-Hujurat (49):13

17 Al-Qur`an, Alî Imrân (3):195 dan al-Nisâ' (4): 32

18 Al-Qur`an, al-Tawbah (9): 72, al-Ahzab (33): 35-36, al-Mu'min (40): 40 dan al-Fath (48): 5 .

${ }^{19}$ Al-Qur’an, al-Hujurat (49): 13.

${ }^{20}$ Al-Qur'an, al-Isrâ' (17): 24, al-Rûm (30): 21, al-Ahqaf (46): 15 dan al-Baqarah (2): 187.

${ }^{21}$ Al-Qur`an, al-Baqarah (2): 228 dan al-Nahl (16): 97.
} 
menolong.22 Keenam, kesempatan mendapatkan pendidikan. Kesempatan memperoleh pendidikan antara laki-laki dan perempuan adalah sama. Ini dapat dilihat dari bagaimana al-Qur`an memberikan pujian kepada orang berprestasi dalam ilmu pengetahuan. Al-Qur'an memberikan penghargaan yang sama bagi mereka yang berprestasi tanpa membedakan jenis kelamin. ${ }^{23}$

\section{Menabrak Ortodoksi, Menakar Realitas}

Dalam budaya masyarakat patriarkhi, ${ }^{24}$ perempuan dianggap makhluk kedua, di mana perempuan tetap didominasi dan disubordinasi oleh sistem baik yang berdasar dari penafsiran berbagai teks keagamaan ${ }^{25}$ maupun dari produk budaya masyarakat. Kekuasaan laki-laki menjadi absolut dan sulit dibatasi dengan argumentasi yang rasional. Laki-laki dapat senantiasa menjadi sumber utama dalam keluarga. Kuasa laki-laki memperingatkan akan ketidakbermaknaan perempuan, bahkan tidak jarang mereka menjadikan suara utama laki-laki dalam keluarga. ${ }^{26}$ Arus utama dalam masyarakat patriarkhal menjadi sistem yang berlangsung dalam kurun waktu yang lama. ${ }^{27}$ Perempuan menjadi bagian dari realitas penindasan dan dehumanisasi pada masyarakat patriarkhal.

22 Al-Qur`an, al-Baqarah (2):177 dan al-Tawbah (9): 71.

${ }^{23}$ Al-Qur`an, al-Mujadalah (58): 11 dan al-Zumar (39): 9.

${ }^{24}$ Kata patriarki secara harfiah berarti kekuasaan bapak atau "patriarkh (patriarch)". Mulanya patriarki digunakan untuk menyebut suatu jenis "keluarga yang dikuasai oleh kaum laki-laki" yaitu rumah tangga besar patriarch yang terdiri dari kaum perempuan, laki-laki muda, anak-anak, budak, dan pelayan rumah tangga yang semuanya berada di bawah kekuasaan laki-laki. Istilah ini kemudian dipergunakan untuk menyebut kekuasaan laki-laki, hubungan kuasa dengan apa laki-laki menguasai perempuan, dan untuk menyebut sistem yang membuat perempuan tetap dikuasai melalui bermacam-macam cara. Kamla Bahsin, Menggugat Patriarki, (Jogyakarta: Kalyanamitra dan Bentang, 1996), hlm.1

25 Fatima Mernissi dan Riffat Hassan, Setara di Hadapan Allah, (Yogyakarta: LSPPA Yayasan Prakarsa, 1995).

26 Penelitian Helen Bouvier menemukan bahwa ketika mereka (perempuan) Madura dimintai pendapat, laki-laki menjadi "juru bicara", sementara suara perempuan diwakilkan (dengan terpaksa) kepada laki-laki. Helen Bouvier, Lebur! Seni Musik dan Pertunjukan dalam Masyarakat Madura, (Jakarta: Forum Jakarta-Paris dan Yayasan Obor, 2002)

${ }^{27}$ Bahsin, Menggugat Patriarki, hlm. xi 
Namun demikian, perubahan sosial dan kebutuhan ekonomi menjadi bagian utama dalam realitas masyarakat. Kekuasaan laki-laki menjadi bagian yang tidak bisa terpisahkan dari realitas dan kebudayaan yang berubah. Kekuatan realitas ini berhadapan dengan teks dan tafsir yang tidak berkembang serta senantiasa tidak bergerak dari realitas yang semakin dinamis. Kekuatan dan kekuasaan laki-laki menjadi unsur dialogis antara realitas dan teks, sehingga tidak mengherankan dalam masyarakat telah terbentuk pemahaman bahwa masyarakat dapat menabrak ortodoksi dengan menakar realitas.

Perempuan bekerja merupakan realitas yang telah berlangsung lama dan menginjak kurun waktu yang tidak bisa dihitung. Dinamika sejarah perempuan menyiasati ortodoksi termasuk norma-norma dan ajaran keagamaan dengan dipadukan terhadap realitas masyarakat. Perempuan bekerja (bahkan dengan kemauan sendiri) merupakan karunia yang patut disyukuri, bahkan dengan penuh kerelaan jika dalam rumah tangga ada kekurangan "belanja dapur", perempuan akan mencari dengan bekerja dalam hal profesi apa pun.

Dalam konsep tersebut tidak memungkinkan teks mewakili seluruh konteks. Dalam pada itu diperlukan adanya interpretasi terhadap teks dengan takaran realitas dan kebudayaan masyarakat. Meskipun tafsir terhadap teks senantiasa memenangkan teks itu sebagai marji' utama dalam pemahaman hukum (Islam), namun senantiasa ada justifikasi terhadap realitas perempuan bekerja. Tafsir realitas ini memungkinkan perempuan bekerja dengan tenggang waktu yang relatif banyak "melebihi" waktu bekerja kaum laki-laki. Pada pagi hari perempuan biasanya telah bersiap dengan segenap pekerjaan rumah mulai dari mencuci, memasak, memandikan anak, serta mengantarkan sekolah sampai batas waktu yang panjang melebihi jam sehari semalam. Bahkan dalam daerah tertentu terjadi pertukaran peran antara laki-laki dan perempuan, misalnya di daerah pesisiran.

Pada daerah pesisiran tersebut, berbeda dengan laki-laki yang memiliki batas dan ruang yang lebih sempit bekerja, perempuan/istri dalam masyarakat pesisir memiliki ruang publik (public-sphare) yang lebih luas. Tidak hanya bekerja dalam sektor rumah tangga (homing), namun juga bekerja sebagai bagian dari pekerjaan ibu (mothering) serta pekerjaan yang dianggap dalam sektor 
publik (public). Bagi tokoh agama pekerjaan yang dilakoni perempuan tersebut tidak menjadi persoalan penting. Hal yang paling penting bahwa pekerjaan tersebut memenuhi ekonomi rumah tangga.

Dalam konteks masyarakat pesisir tersebut, misalnya, bahwa suami dan istri membagi pekerjaan secara sama dan adil. Pekerjaan laki-laki karena dianggap pekerjaan berat, yakni melaut, setelah melaut, menyandarkan dan membersihkan kapalnya, mereka akan bersantai. Karena mereka dianggap telah memenuhi nafkah lahir bagi keluarga. Sedangkan bagi istri secara sadar mengambil peran yang lain yaitu memanfaatkan hasil laut suami untuk meringankan beban ekonomi keluarga.

Bagi masyarakat pesisir, istri mengerjakan pekerjaan yang dikonstruksikan sebagai peran suami merupakan hal biasa. Keterlibatan istri dengan membantu suami akan mendapatkan barakah peningkatan kesejahteraan hidup dan sesuai dengan tuntunan agama (Islam). Pemahaman ini berangkat dari realitas masyarakat pesisir yang keras dan penuh dengan persaingan. Tidak jarang perempuan menjadi tulang punggung keluarga, karena istri dianggap lebih mudah mencari nafkah daripada suami.

Tidak jarang pola pembagian kerja bagi perempuan/istri dan laki-laki/suami pada masyarakat nelayan terfragmentasi dengan jelas. Meskipun dalam banyak hal pembagian ini dapat menembus batas-batas jenis kelamin dan jender. Sejak pagi hari buta -sebelum matahari terbit-perempuan dan laki-laki memiliki aktivitas yang padat baik pada istri maupun suami. Perbedaan antara keduanya bahwa istri lebih berhubungan pada pekerjaan yang disandarkan kepada pekerjaan ibu (mothering) serta pekerjaan yang berkenaan dengan rumah (homing).28 Sejak menjadi ibu dalam rumah tangga, segenap pekerjaan rumah dan ibu dikontruksikan sebagai pekerjaan perempuan..$^{29}$ Tidak terkecuali pekerjaan yang lebih mengarah kepada sektor publik dilakoni sebagai bagian dari pekerjaan istri. Aktivitas semakin padat menjelang siang hingga malam hari. Aktivitas yang bersifat mothering, homing dan public menjadi bagian yang inhern dalam pekerjaan perempuan bahkan seringkali dikerjakan secara

${ }^{28}$ Anke Niehof, The Changing Lives of Indonesian Women: Contained emancipation under Pressure (Leiden: KILV, 1998), 246-253.

${ }^{29}$ Ibid., hlm. 245 
bersamaan. Dalam konteks ini kekuatan perempuan seolah melebihi kekuatan laki-laki. Dengan demikian, laki-laki yang berprofesi sebagai nelayan memiliki waktu luang yang lebih luas daripada perempuan sehingga tidak mengherankan waktu istirahat lebih banyak daripada waktu bekerja, bahkan kadangkala pada saat di darat pekerjaan istri diambil alih oleh suami.

\section{Penutup}

Relasi laki-laki dan perempuan menjadi bahan kajian yang urgen, karena konsep relasi tersebut selalu berkorelasi dengan konsep budaya setempat, baik konsep budaya yang matrialkhal maupun patrialkhal. Di samping itu, banyak tafsiran terhadap teks sumber hukum Islam (al-Qur`an dan al-Hadits) justru menguatkan budaya patrilineal. Tradisi yang bias jender ini mengakar kuat dalam masyarakat. Walaupun demikian, hal yang tidak bisa diingkari adalah perubahan realitas. Saat ini mulai tampak bahwa peran-peran yang secara budaya dikonsepsikan untuk laki-laki justru dilakukan oleh perempuan. Fenomena ini merupakan wujud perubahan realitas, yang akan memunculkan rekonstruksi budaya baru yang egaliter. Karena itu, paradigma baru dalam mengelaborasi teks al-Qur`an dan al-Hadits sebagai sebuah upaya ijtihâd yang tidak bias jender perlu dilakukan dalam merespon fenomena realitas.

\section{Daftar Pustaka}

Bahsin, Kamla. Menggugat Patriarki. Jogyakarta: Kalyanamitra dan Bentang, 1996.

Bouvier, Helen. Lebur! Seni Musik dan Pertunjukan dalam Masyarakat Madura. Jakarta: Forum Jakarta-Paris dan Yayasan Obor, 2002

Engineer, Ali Asghar. Hak-Hak Perempuan dalam Islam. Yogyakarta: LSPPA, 2000.

Fakih, Mansour. Analisi Gender \& Transformasi Sosial. Yogyakarta; Pustaka Pelajar, 1999.

Hidayatullah, Syarif. " Al-Qur'an dan Peran Publik Perempuan “ dalam Gender dan Islam: Teks dan Konteks, ed. Waryono Abdul Ghafur dan Muh. Isnanto. Yogyakarta: PSW IAIN Sunan Kalijaga

Ilyas, Hamim. Studi Kitab Tafsir. Yogyakarta: Teras, 2004

Kadarusman. Agama, Relasi Gender dan Feminesme. Yogyakarta; Kreasi Wacana, 2005. 
Masudi, Masdar F. Islam dan Hak-hak Reproduksi Perempuan. Bandung; Mizan, 1997

Mernissi, Fatima dan Hassan, Riffat. Setara di Hadapan Allah. Yogyakarta: LSPPA Yayasan Prakarsa, 1995.

Niehof, Anke. The Changing Lives of Indonesian Women: Contained emancipation under Pressure. Leiden: KILV, 1998.

Umar, Nasaruddin. Argumen Kesetaraan Jender Perpsektif al-Qur'an. Jakarta: Paramadina, 1999. 